\title{
福島県松川浦における底質の放射性セシウム 濃度と蓄積量の実態把握
}

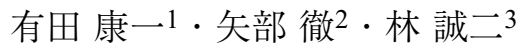 \\ 1正会員 独立行政法人国立環境研究所 生物・生態系環境研究センター \\ （テ305-8506 茨城県つくば市小野川 16-2） \\ E-mail: arita.koichi@nies.go.jp \\ 2独立行政法人国立環境研究所 生物・生態系環境研究センター（テ305-8506 茨城県つくば市小野川 16-2） \\ E-mail: yabet@nies.go.jp \\ 3 正会員 独立行政法人国立環境研究所 地域環境研究センター（テ305-8506 茨城県つくば市小野川 16-2） \\ E-mail: shayashi@nies.go.jp
}

松川浦においては周辺よりも流入する宇多川の上流域において空間線量率が高いことから, 放射性セシ ウムの浦内への初期沈着だけではなく, さらなる流入と蓄積も懸念されている. 本研究では松川浦におけ る放射性セシウムの蓄積様を明らかとすることを目的として, 浦内各所からコア採取した底質の放射性セ シウム濃度測定および性状分析を行なった。放射性セシウムが同程度に高濃度であっても底質性状は異な り, 結果として放射性セシウムの蓄積量も異なった。含泥率の高い南西部では, 放射性セシウムが高濃度 であっても蓄積量は西部よりも少ないことが明らかとなった。松川浦全域の底質 $20 \mathrm{~cm}$ までの総蓄積量は $220 \mathrm{GBq}$ 程度と見積もられ，その $80 \%$ 以上が $15 \mathrm{~cm}$ 以浅に蓄積していることが明らかとなった。

Key Words: radioactive cesium, sediment, inventory, core sampling, Matsukawaura Lagoon

\section{1.はじめに}

2011 年 3 月 11 日に起きた東日本大震災に伴う福 島第一原子力発電所事故により飛散した放射性セシ ウムは, 南東北ならびに北関東各地に大量に沈着す るとともに太平洋に拡散した。生活圈に近く漁業生 産性の高い沿岸浅海域においては, 流域からの流入 に伴うホットスポット形成による外部被ばくリスク や水産物への移行による内部被ばくリスクの低減対 策を講じる必要があり，流域スケールでの放射性セ シウムの移動と集積実態を明らかにすることが必須 の課題となる.

松川浦は福島県浜通り地方に現存する最大の潟湖 である。文部科学省による第 4 次航空モニタリン グ1)の結果, 周辺地表面への放射性セシウム 137 の 沈着量は $10-60 \mathrm{kBq} / \mathrm{m}^{2}$ とされ, 相対的に低污染地域 といえる，浜通り地方を流れる河川においては，全 般的に上流域の污染状態が下流域と比べて著しく高 く, 松川浦に流入する宇多川上流域の沈着量は 100-300 kBq/ $\mathrm{m}^{2}$ とされている. そのため, 松川浦は, 上流からの流入土砂に伴われた高濃度セシウムの集
積が生じやすい状況にあるといえる

さらに, 事故後 3 年を経てもなお水産物の出荷制 限を余儀なくされている実情を踏まえ, 一日でも早 い水産漁業に根ざした復興を目指すうえでも，浦内 に扔ける放射性セシウムの集積実態の把握と, 今後 の推移を明らかにすることは喫緊の課題である。底 質中の放射性セシウムは安定的に吸着しており，䀣 濁態や溶存態として水中に滞留・移動する放射性セ シウムよりも高濃度であることから ${ }^{2-4)}$, その実態把 握は今後の除染等対策を検討する上で極めて重要な 取り組みである。

以上を鑑み，本研究では松川浦底質における放射 性セシウムの水平・鉛直方向の蓄積実態を把握する とともに, 底質性状との関係から蓄積特性を明らか にすることを試みた。

\section{2. 材料と方法}

調查対象地の松川浦は, 宮城県との県境である福 島県相馬市に位置しており, 航路として利用されて 


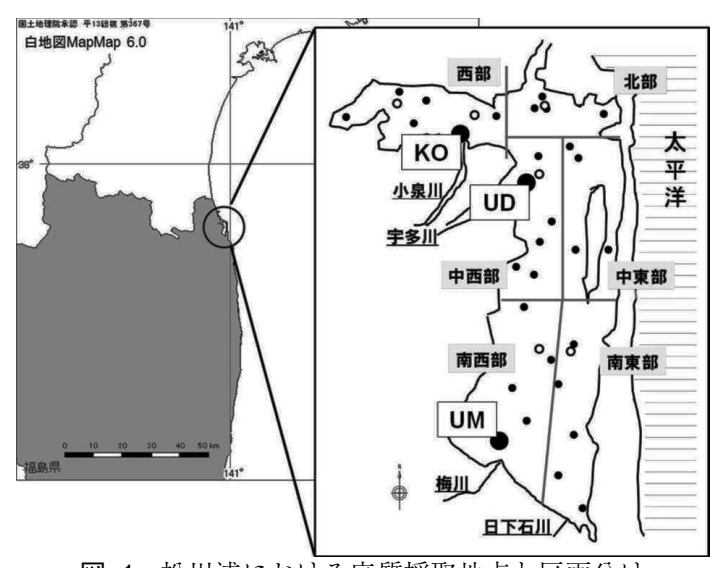

図-1 松川浦における底質採取地点と区画分け

いる澪筋以外は水深 $1 \mathrm{~m}$ 程度と浅く, 干潮時には干 潟が広範囲に現れる面積 $6.46 \mathrm{~km}^{2}$ の潟湖である ${ }^{5-7)}$. 北部にある水路（浦口）によってのみ太平洋とつな がる閉鎖性水域であり，潮汐による海水交換率は悪 く，海水が流入する浦口部から浦奥部にかけて表層 水の塩分濃度は低下する傾向にある ${ }^{8)}$. 小泉川, 宇 多川, 梅川ならびに日下石川の計 4 河川が流入して おり，全流域面積の $60 \%$ 以上を宇多川が占め ${ }^{9-12)}$, 平均流量は $1.81 \mathrm{~m}^{3} / \mathrm{s}$ と小泉川の約 3 倍である ${ }^{13)}$. 太平洋沿岸域漁業の拠点であると同時に春から秋に かけてのアサリ漁, 秋から冬にかけてのアオノリ（ヒ

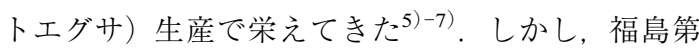
一原子力発電所事故の影響をうけ, 現在もなお浦内 に扔ける水産漁業再開の目処はたってはいない.

図-1に松川浦内の底質採取地点を示した。福島水 産試験場の調查定点 ${ }^{14)}$,15) 参考に選定し, 現場の底 質状況に応じて最終決定した 30 地点（図内○）では 2013 年 7 月に, 浦内の代表的な澪筋に設定した 6 地 点（図内○）では同年 11 月にそれぞれ底質を採取し た. エクマンバージ式採泥器に代表されるグラブ型 採泥器は表層浮泥等細粒分も含めた鉛直的に乱れの ないサンプル採取には不向きであるため ${ }^{16)}$, 底質採 取には内径 $10 \mathrm{~cm}$ のアクリル製柱状採泥器を用い た。底質に吸着した放射性セシウムは, 潮汐の影響 などにより均一に分布するのではなく，パッチ状に 分布することが予想されることから，それぞれの地 点において $5 \mathrm{~m}$ 四方内で $20 \mathrm{~cm}$ 深の底質コアを 2 本 採取した．採取後すぐに $5 \mathrm{~cm}$ ごとにコアを切り分 け，チャック付きビニル袋に収納，冷蔵保管した。

多量のサンプルを迅速に効率よく測定するため に, 湿潤状態の底質サンプルについて放射性セシウ 厶 $\left({ }^{134} \mathrm{Cs},{ }^{137} \mathrm{Cs}\right)$ を測定した後, 乾湿比を求める手 法 ${ }^{17)}$,18) を採用した. 各地点各層ごとに底質サンプ ル全重量を測定した後，2本の底質コアを十分に擋
拌してポリプロピレン製 U-8 容器に充填した，放射 性セシウムの測定には, ゲルマニウム半導体検出器 を用いた ${ }^{19)}$ 。使用した機種は, GMX45P4-76 (ORTEC 社 製), GEM40P4-76 (ORTEC 社 製), GEM35-70, GEM20-70（ORTEC 社製）であり，それぞれ放射能 標準ガンマ体積線源（アルミナ）MX033U8PP（(社） 日本アイソトープ協会）を用いて校正を行なった. 全てのサンプルについて放射性セシウムが検出され るまで測定した結果, 測定時間は 780 秒から 64,000 秒であった。測定結果はサンプル採取日の放射能濃 度に補正した值を用いた。

湿潤重量あたりの放射性セシウム濃度を乾燥重量 あたりに換算するために, 底質の乾湿比を求めた. サンプルの有効利用と迅速な処理を実現するため に，放射性セシウムの測定が終了したサンプルを用 い, U-8 容器に充填した状態で乾燥させた。一般的 な乾燥手法 $\left.\left.{ }^{17)}, 18\right), 20\right)$ を参考にしたうえで, 底質の蓄 熱による容器の変形をさけるために, ポリプロピレ ンの一般的な耐熱温度 $\left(100-140^{\circ} \mathrm{C}\right)$ よりも十分に低 い $80^{\circ} \mathrm{C}$ とした。一方で乾燥時間を長く設定し, 40 時 間以上で十分に恒量に達したことを確認した。

各底質採取地点に扔ける放射性セシウム濃度に各 層ごとのコア重量を乗じ，コア面積で除すことによ り蓄積量 (inventory)を地点ごと各層ごとに算出した. さらに, 各地点で得られた蓄積量デー夕を基に浦内 への総蓄積量を推定するため, 地理情報システム ArcGIS10.0 において逆距離荷重補間（inverse distance weighted interpolation: IDW) やスプライン関数, kriging 等複数の空間内挿補間法を用いて試行的に検 討した. その結果, 手法間で分布傾向や総蓄積量の 差が比較的小さかったことから, 航空機モニタリン グによるマッピング方法 ${ }^{21)} に$ 準拠して IDW を採用

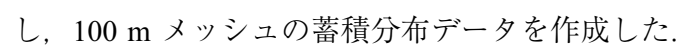

浦内に扮ける底質中の放射性セシウム濃度や蓄積 量の水平分布特性を検討するため, 採取地点は区画 漁業権 ${ }^{22}$ を参考に, 全採取地点を 6 区画（北部，西 部, 中西部, 中東部, 南西部, 南東部) に区分した. さらに, 主要流入河川の流入域については, それぞ れ西部に位置する小泉川流入域の地点を KO, 中西 部に位置する宇多川流入域の地点を UD, 南西部に 位置する梅川流入域の地点を UM とした。

放射性セシウム測定用サンプルとは別に，底質を $110^{\circ} \mathrm{C}$ にて 24 時間乾燥後, $600^{\circ} \mathrm{C}$ で 3 時間処理して重 量の差分を算出することにより強熱減量を求め, 底 質に含まれる有機物の指標とした，粒径分布を求め るために，湿式ふるい法により Wentworth ${ }^{23)}$ の粒径 区分に基づく目合 $2,000,1,000 ， 500 ， 250 ， 125 ， 63$ $\mu \mathrm{m}$ にて底質を分画した。各画分については，粒径 


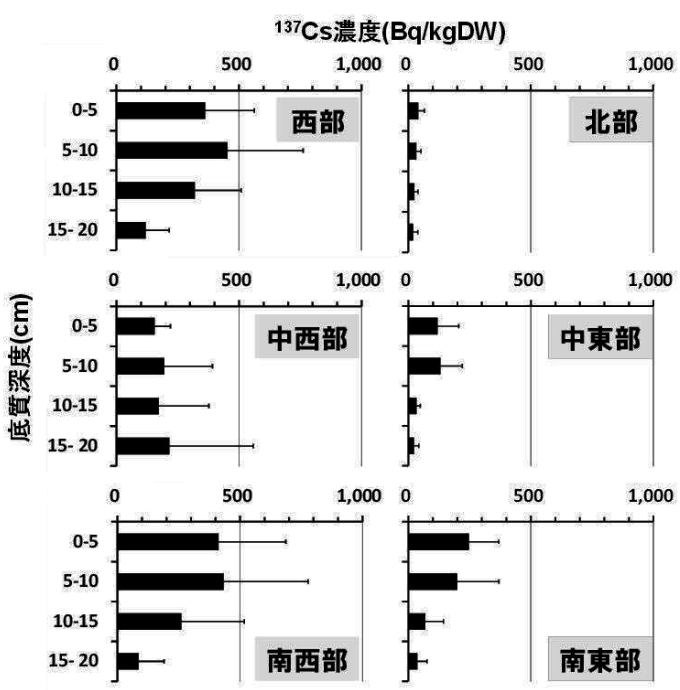

図-2 底質採取区画ごとのセシウム 137 平均濃度の鉛直 分布

2, $000 \mu \mathrm{m}$ より大きい画分を礫， 1,000-2,000 $\mu \mathrm{m}$ 画 分を極粗粒砂, 500-1,000 $\mu \mathrm{m}$ 画分を粗粒砂, 250-500 $\mu \mathrm{m}$ 画分を中粒砂, 125-250 $\mu \mathrm{m}$ 画分を細粒砂, 63-125 $\mu \mathrm{m}$ 画分を極細粒砂とし，シルトと粘土とを 含む $63 \mu \mathrm{m}$ 未満画分を泥画分 (含泥率) とした.

\section{3. 結果と考察}

\section{（1）放射性セシウム濃度評価}

a）放射性セシウム濃度の水平・鉛直分布

測定で得られたセシウム $134\left({ }^{134} \mathrm{Cs}\right)$ 濃度ならび にセシウム $137\left({ }^{137} \mathrm{Cs}\right)$ 濃度を, それぞれの半減期に 基づき, 福島第一原子力発電所の事故日へ減衰補正 した結果, ${ }^{134} \mathrm{Cs} /{ }^{137} \mathrm{Cs}$ 比は $0.97 \pm 0.077$ であった. 東京電力株式会社により発表された事故由来放射性 セシウムの ${ }^{134} \mathrm{Cs} /{ }^{137} \mathrm{Cs}$ 比は，ほぼ 1 であることから， 本研究で採取した底質コアサンプル中の放射性セシ ウムの大部分は，事故に由来するものであることが 確認された。一部の地点では, $20 \mathrm{~cm}$ 以深において も事故由来の放射性セシウムが蓄積している可能性 があるため, 本稿で示す放射性セシウム蓄積量は, 実際と比べて過小評価していることが示唆された。 以上を踏まえつつ，また，底質サンプル採取時期が 2 期にわかれていることから, 以降の結果と考察につ いては, より半減期の長い ${ }^{137} \mathrm{Cs}$ を扱うこととした.

各地点における底質乾燥重量あたりの放射性セシ ウム $\left({ }^{137} \mathrm{Cs}\right)$ 濃度の水平・鉛直分布を図-2に示した。 各区画における $0-5 \mathrm{~cm}$ 層の平均 ${ }^{137} \mathrm{Cs}$ 濃度（土標準 偏差）は，それぞれ西部 $360 \pm 200 \mathrm{~Bq} / \mathrm{kgDW}$, 北部
$39 \pm 26 \mathrm{~Bq} / \mathrm{kg} \mathrm{DW}$, 中西部 $150 \pm 66 \mathrm{~Bq} / \mathrm{kg} \mathrm{DW}$, 中 東部 $120 \pm 88 \mathrm{~Bq} / \mathrm{kg} \mathrm{DW}$, 南西部 $410 \pm 280 \mathrm{~Bq} / \mathrm{kg}$ $\mathrm{DW}$, 南東部 $250 \pm 120 \mathrm{~Bq} / \mathrm{kg} \mathrm{DW}$ であった。すなわ ち, 水平方向には南高北低, 西高東低の傾向があり, 浦口から離れているために海水交換が及びにくい浦 奥の南西部や，より閉鎖的な環境を呈する西部にお いて高濃度であり，浦口に近い北部が最も低濃度で あることが示された，流入する河川の影響も考えら れ，西部の小泉川流入域に位置する地点 $\mathrm{KO}$ や, 南 西部の梅川流入域に位置する地点 UM おいては, そ れぞれ $840 \mathrm{~Bq} / \mathrm{kg}$ DW および $870 \mathrm{~Bq} / \mathrm{kg} \mathrm{DW}$ と高濃度 であった。底質採取調査とは独立して, 多項目水質 計（WQC-24,TOA DKK）による水質調査を 8 月の小 潮満潮時に行なった。塩分濃度は 26-31 psuであり， 浦口付近から浦奥部にかけて低下傾向を示したが全 体的に塩分濃度が高い環境といえた。したがっ て, ${ }^{137} \mathrm{Cs}$ が吸着した河川由来懸濁態粒子が, 塩分濃 度の上昇にともなって, 流入域で速やかに凝集沈殿 を起こしている可能性も考えられた。

一方，鉛直方向には 0-5 cm 層もしくは 5-10 cm 層 において高濃度となり，10-15 cm 以深で低下する傾 向にあることが明らかとなった。要因としては，潮 汐や風浪による擋乱に伴う底質の再懸濁と堆積, お よび鉛直混合が $10 \mathrm{~cm}$ 程度の深さまで，常に繰り返 されている可能性が考えられた。西部における鉛 直分布は特徵的であり，表層から下層までほぼ均一 の鉛直濃度分布となった。地点 UDより南に位置す る 4 地点において, 他区域と同様に0-10 cm 層に濃 度ピークがあるのに対して, 地点UDも含めた宇多 川流入域に位置する 3 地点においては，下層ほど高 濃度となる傾向にあったためである。とくに地点 UDにおいては，下層ほど高濃度となる傾向が強く, 表層 0-5 cm 層における ${ }^{137} \mathrm{Cs}$ 濃度が $150 \mathrm{~Bq} / \mathrm{kg} \mathrm{DW}$ に 対して，15-20 cm 層における濃度は $960 \mathrm{~Bq} / \mathrm{kg} \mathrm{DW}$ であった。宇多川流入域に下層で高濃度を示す地点 が存在することは, 本調査により初めて明らかと なったことであり，柱状採泥器を用いた底質コアサ ンプリングの重要性が改めて示された。

b）放射性セシウム濃度と底質性状との関係

放射性セシウム濃度と底質との関係は，シルト・ 粘土を含んだ粒径の細かい画分（含泥率）や有機物 との関係で説明されていることが多(2),14),24),25). 本調査において相対的な高濃度といえる 1,000 $\mathrm{Bq} / \mathrm{kg} \mathrm{DW}$ 前後の ${ }^{137} \mathrm{Cs}$ 濃度を，いずれかの層におい て呈した 3 地点について ${ }^{137} \mathrm{Cs}$ 濃度と底質粒径の鉛 直分布とを比較して図-3に示した。いずれも河川流 入域の地点ではあるが, 日下石川流入域の最高濃度 は $460 \mathrm{~Bq} / \mathrm{kg}$ DW であったことから対象外とした。 


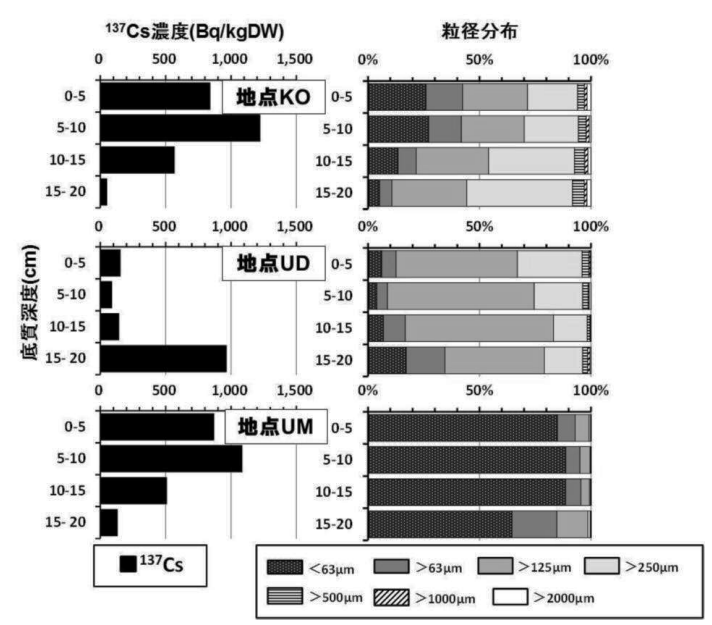

図-3 高濃度を呈する 3 地点（地点 KO, UD, UM）におけ るセシウム 137 濃度および底質粒径の鉛直分布

小泉川流入域の地点 $\mathrm{KO}$ と梅川流入域の地点 $\mathrm{UM}$ とを比較すると, ${ }^{137} \mathrm{Cs}$ 濃度の鉛直分布は類似するも のの, 粒径分布は異なっていることが明らかとなっ た.地点 $\mathrm{KO} に$ に打り $15 \mathrm{~cm}$ 深までの底質は 125-250 $\mu \mathrm{m}$ の細粒砂画分および 250-500 $\mu \mathrm{m}$ の中粒 砂画分によって $50 \%$ 以上が占められており, $63 \mu \mathrm{m}$ 未満の泥画分 (含泥率) は $22 \pm 6.2 \%$ であった。一 方, 地点 UMの底質は全層にわたり泥画分が大部分 を占め, $15 \mathrm{~cm}$ 深までの平均含泥率は $87 \pm 1.8 \%$ で あった。 それぞれの地点に扔ける $15 \mathrm{~cm}$ 深までの平 均強熱減量も異なり, 地点 KO では $4.2 \pm 1.0 \%$, 地 点 UM では $9.9 \pm 0.2 \%$ であった，以上より，梅川 流入域における底質は，泥質で有機的であるのに対 して，小泉川流入域に扔ける底質は，相対的に粒径 が大きくかつ有機物が少ないことが示された.

宇多川流入域の地点 UD の粒径分布は, 125-250 $\mu \mathrm{m}$ の細粒砂画分が優占することから, 前述の 2 地 点とは性状が異なる底質であることが確認された。

15-20 cm 層において $63 \mu \mathrm{m}$ 未満の泥画分と 63-125 $\mu \mathrm{m}$ の極細粒砂画分との割合が増加していることか ら, ${ }^{137} \mathrm{Cs}$ 濃度がピークとなる要因と考えられた。同 時に, 当該層以浅に比べて大きく異なる性状の底質 が存在しているわけではないことも示された，流域 面積が広く流量も多い宇多川流域において, 大雨に よる増水に伴い, 初期沈着した ${ }^{137} \mathrm{Cs}$ が懸濁態粒子と して大量に流入, 沈殿, 堆積した後, $15 \mathrm{~cm}$ 以深を残 して表層の ${ }^{137} \mathrm{Cs}$ 吸着懸濁態粒子は流出・拡散した結 果と推察することもできるが，定かではない．

以上より, 必ずしも泥分 (含泥率) や有機物量 (強 熱減量)によって, ${ }^{137} \mathrm{Cs}$ 濃度の高低が決まるわけで はないことが確認され, 底質の性状が異なっていて
も ${ }^{137} \mathrm{Cs}$ が同程度に高濃度に存在し，同様の鉛直分布 を示す場合もあることが明らかとなった，河川流入 域ごとに粒径分布が異なっていた要因としては, 河 川ごとに由来する ${ }^{137} \mathrm{Cs}$ 吸着懸濁態粒子の組成が異 なる可能性と, 浦内における潮汐に伴う底質の流動 特性が寄与している可能性とが考えられた。

\section{（2）放射性セシウム蓄積量評価}

a）放射性セシウム濃度と蓄積量との関係

それぞれの区画に位置する底質採取地点における 底質コア深度ごとの放射性セシウム濃度と蓄積量と の関係を図-4に示した，基本的には線形関係にある ものの, ${ }^{137} \mathrm{Cs}$ 濃度が $500 \mathrm{~Bq} / \mathrm{kg}$ DW 以上となると, 特徵的な地点が存在することが示された。とりわけ 南西部において顕著であり, $15 \mathrm{~cm}$ 層までの各層にお いて, 濃度に比して相対的に蓄積量が少ない傾向が みられた。 $0-5 \mathrm{~cm}$ ならびに 5-10 cm 層において最高 濃度を呈した 2 地点は, 西部の小泉川流入域に位置 する地点 $\mathrm{KO}$ および南西部の梅川流入域に位置する 地点 UMであった。これら地点の底質中の放射性セ シウム濃度は同程度であるにもかかわらず, 蓄積量 に関しては, 地点 $\mathrm{KO} に$ におる $0-20 \mathrm{~cm}$ 深までの值 は地点 UMの 2.1 倍に相当する $130 \mathrm{kBq} / \mathrm{m}^{2}$ となり, 異なることが確認された。一方，15-20 cm 層でこれ ら 2 地点と同等に高濃度を示しているのは, 中西部 に位置し，下層ほど高濃度となる宇多川流入域の地 点 UD であり，当該層における ${ }^{137} \mathrm{Cs}$ 濃度ならびに 0-20 cm 深までの全蓄積量は，それぞれ $960 \mathrm{~Bq} / \mathrm{kg}$ DW と $77 \mathrm{kBq} / \mathrm{m}^{2}$ であった。

以上より， ${ }^{137} \mathrm{Cs}$ 濃度と蓄積量とは必ずしも一対一 に対応していない場合があることが示された. Kusakabe et al. ${ }^{26)}$ は, ${ }^{137} \mathrm{Cs}$ 濃度と蓄積量との関係が, 底質のかさ密度 (bulk density)により異なることを示 した，かさ密度が相対的に小さい底質において は, ${ }^{137} \mathrm{Cs}$ 蓄積量が濃度に比して相対的に少ない傾向 にあり, かさ密度が相対的に大きい底質においては, 濃度に比して蓄積量が相対的に多いことが示され た. 本研究において明らかとなった ${ }^{137} \mathrm{Cs}$ 濃度と蓄積 量との関係について, 底質密度による検証を試みた。

b）放射性セシウム蓄積量と底質密度との関係

底質採取地点に扔ける鉛直方向の底質状態を反映 した指標として, 単位コア体積あたりの底質乾燥重 量密度 $\left(\mathrm{gDW} / \mathrm{cm}^{3}\right)$ を定義して層別に求めた。 以下, 単に底質密度と表現する。底質状態とは採取した底 質コアそのものを示し, 底質性状である粒径分布や 含泥率, 強熱減量 (有機物量), 空隙率や水分量, 粘 度等を分けるのではなく, 総合して現場における底 質コアのあり様として評価することを試みた，本研 

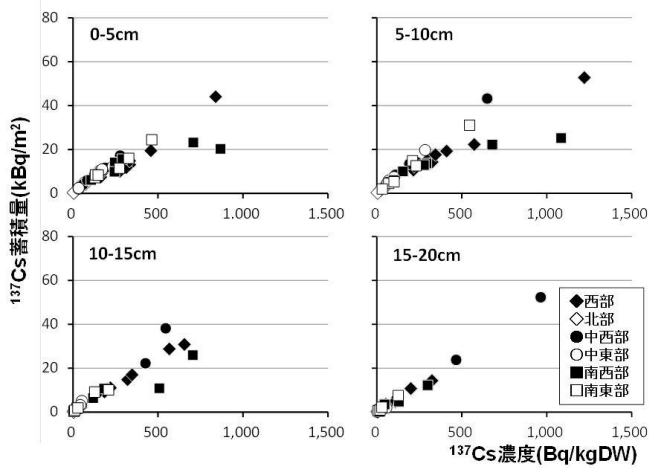

図-4 各区画の地点ごとにおける底質コア各層のセシウ ム 137 濃度と蓄積量との関係

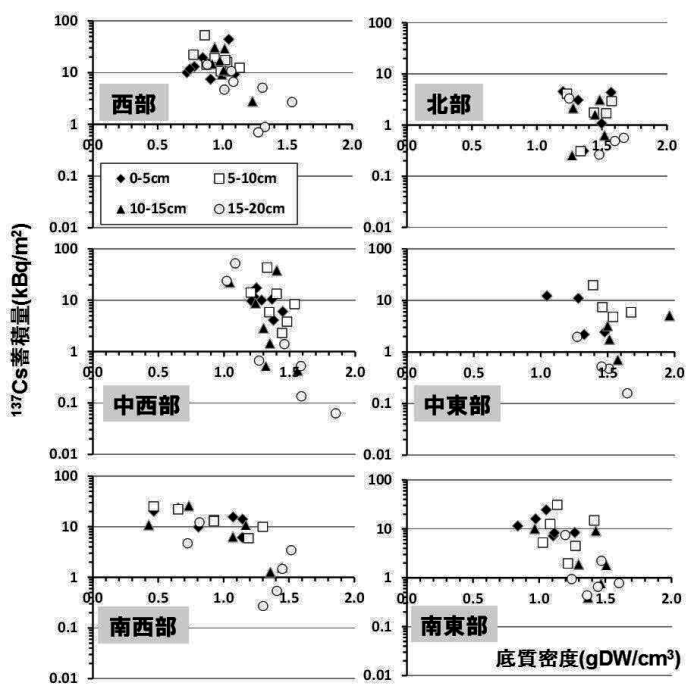

図-5 単位コア体積あたりの底質乾燥重量密度とセシウ ム 137 蓄積量との関係

究に扮ける底質密度とは, 厳密な意味では, かさ密 度や土粒子の密度 ${ }^{27)}$ とは異なる指標である。

底質密度と ${ }^{137} \mathrm{Cs}$ 蓄積量との関係を，区画ごとに分 けて片対数グラフで図-5に示した，すべての区画に おいて, 基本的には密度の低下とともに ${ }^{137} \mathrm{Cs}$ 蓄積量 が増加する傾向にあることが明らかとなり, $1.0 \mathrm{~g}$ $\mathrm{DW} / \mathrm{cm}^{3}$ 前後で最大值を示す傾向もみられた。 図-4 において特徵的な分布を示した南西部および中西部 では，その変化度合いに差がみられた，南西部では， 底質密度変化に対する ${ }^{137} \mathrm{Cs}$ 蓄積量変化が相対的に 小さく, 反対に中西部では, 底質密度変化に対して 蓄積量変化が相対的に大きい傾向にあることが示さ れたことから，区画によって，底質密度範囲と ${ }^{137} \mathrm{Cs}$ 蓄積量との関係が異なると考えられた，底質密度範 囲を 3 グループに分類し, 最も ${ }^{137} \mathrm{Cs}$ 蓄積量が少ない 北部の密度範囲 1.2-1.7 g DW/ $\mathrm{cm}^{3}$ を基準として, 西 部や南東部で確認される密度範囲 0.7-1.2 g
$\mathrm{DW} / \mathrm{cm}^{3}$ ，ならびに南西部のみで確認される密度範 囲 0.4-0.7 $\mathrm{g} \mathrm{DW} / \mathrm{cm}^{3}$ とした。

西部や南東部においては, 密度範囲 0.7-1.2 g $\mathrm{DW} / \mathrm{cm}^{3}$ において ${ }^{137} \mathrm{Cs}$ 蓄積量が多くなる傾向にあ り，小泉川流入域の地点 KO が該当した，北部や中 東部においては, この密度範囲の底質が潮汐の影響 によって沿岸海域へ流出している可能性が高く, 結 果として蓄積量が相対的に少ない可能性が示され た。中西部において ${ }^{137} \mathrm{Cs}$ 蓄積量が多い宇多川流入 域の地点 UD では, $15 \mathrm{~cm}$ 以深に密度範囲 0.7-1.2 g $\mathrm{DW} / \mathrm{cm}^{3}$ の底質が存在し, 蓄積量が多くなっている ことが明らかとなった。近接する澪や他の地点で は, 北部と同じ密度範囲 $1.2-1.7 \mathrm{gDW} / \mathrm{cm}^{3}$ の底質に 蓄積していることが示されたことから, 宇多川流域 からの ${ }^{137} \mathrm{Cs}$ の継続的な負荷の可能性も考えられた. より低密度な底質が南西部のみで確認されたことに より, 潮汐による海水交換の影響が及びにくい区画 であることが示された。 ${ }^{137} \mathrm{Cs}$ 濃度に比して蓄積量 が相対的に少ない傾向にある, 梅川流入域の地点 $\mathrm{UM}$ における 0-15 $\mathrm{cm}$ 層までの底質密度は, $0.5 \mathrm{~g}$ $\mathrm{DW} / \mathrm{cm}^{3}$ 未満と相対的に最も低いことから, Kusakabe et al. ${ }^{26)}$ が示した条件と一致した。これまで の知見を合わせると, 梅川流入域の地点 UM の底質 は含泥率が高く, 強熱減量も多く有機的で, 底質密 度が低いために ${ }^{137} \mathrm{Cs}$ 濃度に比して蓄積量が相対的 に少ないと特徴づけることができた。

c）松川浦全域における放射性セシウムの蓄積に対す る流入フラックスの寄与

松川浦全域における ${ }^{137} \mathrm{Cs}$ 蓄積量分布推定結果を 図-6に示した。松川浦底質 $20 \mathrm{~cm}$ 深までの総蓄積量 は $220 \mathrm{GBq}$ 程度, 平均蓄積量は $34 \mathrm{kBq} / \mathrm{m}^{2}$ と見積も られ, その $80 \%$ 以上が $15 \mathrm{~cm}$ 以浅に蓄積しているこ とが明らかとなった。

底質への蓄積に対する流入フラックスの一つであ る潟湖水面への直接沈着量を推定するため, 文部科 学省により 2011 年 10 月 22 日から 11 月 5 日にかけ て実施された第 4 次航空機モニタリング1)による ${ }^{137}$ Cs 沈着量デー夕を基に, ArcGIS10.0 を用いて松川 浦周縁 $(100 \mathrm{~m})$ 陸地の平均沈着量を算定したところ, 平均蓄積量とほほ同程度の $35 \mathrm{kBq} / \mathrm{m}^{2}$ となった。潟 湖水面への直接沈着成分が, どの程度直接沿岸海域 へ流出したかは不明であるが，北部に比べ潮汐によ る海水交換量比の小さい南部については, 両者の值 の比較から, 蓄積量に対して直接沈着量が相当量寄 与していることが推察された。

一方で, 浦内での放射性セシウム蓄積分布は, 空 間的に極めて不均一であり, 浦口から離れた南西部 よりも浦口に近く閉鎖性の強い西奥部において蓄積 


\section{4. まとめ}

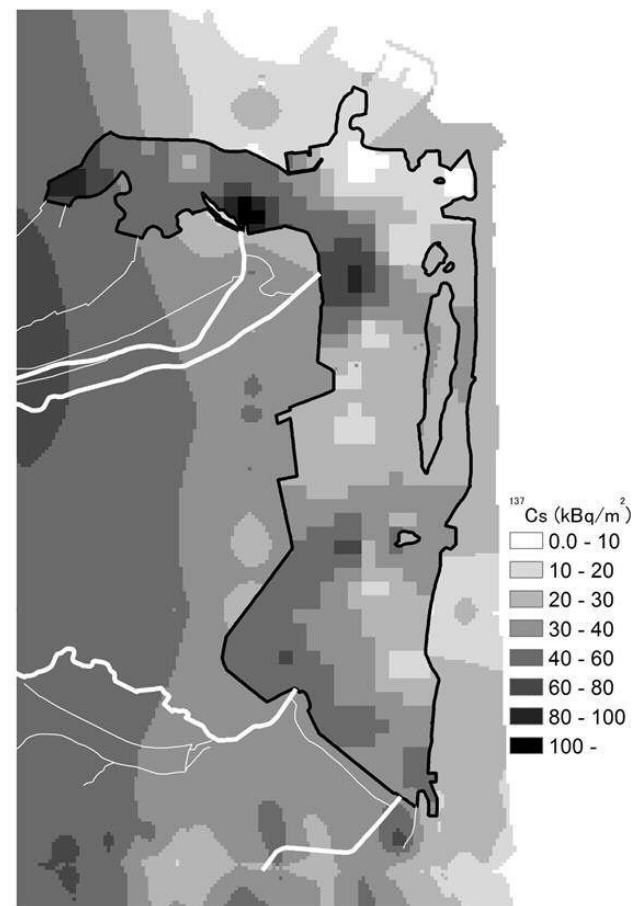

図-6 松川浦におけるセシウム 137 蓄積分布推定図（100 $\mathrm{m}$ メッシュ)

量が多く，小泉川および宇多川流入域の蓄積量も多 い. これらは，流域からの寄与を強く示唆する結果 であることから，流入 4 河川の流域面積ならびに土 地利用状況を ArcGIS10.0 を用いて算定するととも に，流域沈着量を算定した。全流域面積の $66 \%$ を占 める $100 \mathrm{~km}^{2}$ ありの宇多川流域には, 全流域に沈着 した ${ }^{137} \mathrm{Cs}$ の $84 \%$ が沈着していると算定され，平均 沈着量は松川浦底質における平均蓄積量の約 10 倍 となる $330 \mathrm{kBq} / \mathrm{m}^{2}$ であった。松川浦への流入負荷 源としての寄与率は, 宇多川が最も大きいと考えら れるが, 降雨時の土壤流出特性は流域の土地利用状 況によって異なると考えられる。宇多川流域は $80 \%$ が森林であるが, 梅川や日下石川流域では水田と森 林とを合わせて $70 \%$ 程度であった。 小泉川流域では 市街地が $13 \%$ を占め, 土地利用に占める割合が 4 河 川中で最も大きかった。今後の污染の推移を明らか にする上でも，土地利用状況も考慮した流域ごとの 寄与割合を定量評価することが不可欠と言える.
除染を含めた環境修復と水産漁業の復興を四るた めには，水域における放射性セシウムの分布実態と その推移を把握することが重要である。福島県相馬 市に位置する松川浦における底質中の放射性セシウ 么濃度および蓄積量の水平・鉛直分布を明らかとす ることを目的として，底質コアサンプリングを実施 した。 その結果, 濃度と蓄積量はともに西高東低, 南高北低の水平分布を示し, 鉛直方向には $15 \mathrm{~cm}$ 以 深で低下する傾向にあることが示された，宇多川流 入域においては，下層ほど高濃度を呈することが初 めて明らかとなり, 柱状採泥器によるサンプリング の重要性が確認された。 ${ }^{137} \mathrm{Cs}$ 濃度と蓄積量とは, 必 ずしも一対一に対応するとは限らず，含泥率が高く 単位コア体積あたりの底質乾燥重量密度が相対的に 小さい底質においては, 濃度に比して蓄積量が低い 傾向にあることが示された。 各区画における単位コ ア体積あたりの底質乾燥重量密度の分布から, 浦内 における底質流動と ${ }^{137} \mathrm{Cs}$ 蓄積量との関係も示唆さ れた。松川浦における総蓄積量が $220 \mathrm{GBq}$ と見積も られ，80\%以上が $15 \mathrm{~cm}$ 以浅に蓄積していることが 明らかとなった。全域における蓄積実態が明らかと なり, 河川流域からの寄与が示唆された. 今後は, 河川からの流入ならびに浦口からの流出特性調査を 行ない，松川浦における放射性セシウム収支を算定 し，污染の推移を明らかにしていきたい。

謝辞：本研究は環境省「平成 25 年度環境中の放射性 物質の動態解明及び放射性物質に污染された廃棄物 等の効率的な処理処分等研究委託業務」の一環とし て実施された。本調査を実施するにあたっては相馬 双葉漁業協同組合の多大なるご理解・ご協力をいた だいた。ここに謝意を表します。

\section{参考文献}

1）文部科学省：文部科学省による第 4 次航空機モニ夕 リング測定結果について, http://radioactivity.nsr.go.jp/ja/ list/362/list-1.html, 2011, 2014 年 5 月 22 日アクセス.

2) He, Q. and Walling, D. E. : Interpreting particle size effects in the adsorption of ${ }^{137} \mathrm{Cs}$ and unsupported ${ }^{210} \mathrm{~Pb}$ by mineral soils and sediments, Journal of Environmental Radioactivity, Vol. 30, No. 2, pp. 117-137, 1996.

3）青野辰雄 : 河川, 湖沼や海洋へ堆積する放射性セシウ ムについて, Isotope News, No. 699, pp. 12-13, 2012.

4）添盛晃久, 小豆川勝見, 野川憲夫, 桧垣正吾, 松尾基 之: 東京湾底質における福島第一原子力発電所事故 由来の放射性セシウムの濃度変化, 分析化学, Vol. 62, 
No. 12, pp. 1079-1086, 2013.

5）環境省：閉鎖性海域ネット 27. 松川浦, http://www.env.

go.jp/water/heisa/heisa_net/waters/matukawaura.html, 2014 年 5 月 22 日アクセス.

6）（公財）国際エメックスセンター：日本の閉鎖性海域 27 松川浦, http://www.emecs.or.jp/closedsea-jp/kaiiki/pdf/ 054.pdf, 2014 年 5 月 22 日アクセス.

7）国土地理院地理調査部：湖沼湿原調査報告書（松川浦 地区), 国土地理院技術資料 D1-No. 574, 34pp., 2011.

8）加茂崇, 山下善, 涌井邦浩, 鷹㟝和義, 神山享一, 西隆一 郎, 林健太郎: 福島県松川浦の東日本大震災津波前後 での水質変化, 水路, No. 163, pp. 6-12, 2012.

9）寺中啓一郎, 安田禎輔, 長林久夫, 濱田好洋, 松村憲 佳 : 福島県河川の河口現地調査, 湾岸工学論文集, Vol. 37, pp. 349-353, 1990.

10）福島県：宇多川水系河川整備基本方針 松薰る緑豊 かなふる郷にめぐみの流れいつまでも〜明日に飛躍 する活力の源として〜, 9pp., 1990.

11）福島県：二級河川梅川水系河川整備基本方針 松薰 る緑豊かなふる郷にめぐみの流れいつまでも〜明日 に飛躍する活力の源として〜, 7pp., 2008.

12）福島県：二級河川小泉川水系河川整備基本方針 松 薫る緑豊かなふる郷にめぐみの流れいつまでも〜明 日に飛躍する活力の源として〜, 7pp., 2009.

13）福島県生活環境部：久慈川等に係る水生生物の保全 に係る水質環境基準の水域類型指定 (案), 15pp., 2007.

14）神山享一, 島村信也：松川浦の海底土における放射性 セシウムの分布, 福島県水産試験場研究報告, No. 16, pp. 91-96, 2013.

15）鷹㟝和義 : 松川浦の底質（含泥率）水平分布調査（震 災以降の推移), 平成 23 年度福島県水産試験場, 水産 種苗研究所事業概要書, pp. 59-60, 2013.

16）いであ株式会社：平成 24 年度水環境中の放射性物質
調査法等検討業務, 179pp., 2013.

17）文部科学省：緊急時におけるガンマ線スペクトロメ トリーのための試料前処理法, 放射能測定法シリーズ 24, 50pp., 1992.

18）文部科学省: 緊急時におけるガンマスペクトル解析 法, 放射能測定法シリーズ 29, 174pp., 2004

19）文部科学省：ゲルマニウム半導体検出器によるガン マ線スペクトロメトリー, 放射能測定法シリーズ 7, 362pp., 1992.

20）日本工業標準調査会：JISA1203 土の含水比試験法, http://www.jisc.go.jp, 2014 年 5 月 22 日アクセス.

21）（独）日本原子力研究開発機構福島研究開発部門：航 空機モニタリング報告書, http://fukushima.jaea.go.jp/init iatives/cat03/pdf/4.4.pdf, 2014 年 5 月 22 日アクセス.

22）佐藤利幸, 尾形康夫, 根本芳春, 島村信也 : 福島県松川 浦におけるアサリ漁業の変遷と現状における問題点, 福島県水産試験場研究報告, No. 14, pp. 57-67, 2007.

23) Wentworth, C. K. : A scale of grade and class terms for clastic sediments, The Journal of Geology, Vol. 30, No. 5, pp. 377-392, 1922.

24）百島則幸, 上田祐介, 杉原真司, 山形陽一, 国分秀 樹 : ${ }^{210} \mathrm{~Pb}$ 堆積年代測定法による英覻湾の堆積環境の 解析, 地球化学, Vol. 42, No. 3, pp. 99-111, 2008.

25）日下部正志 : 海洋における人工放射性核種の動態, 海 洋と生物, Vol. 34, No. 3, pp. 217-230, 2012.

26) Kusakabe, M., Oikawa, S., Takata, H. and Misonoo, J. : Spatiotemporal distributions of Fukushima-derived radionuclides in nearby marine surface sediments, Biogeosciences, Vol. 10, No. 7, pp. 5019-5030, 2013.

27）日本工業標準調査会：JISA1202 土粒子の密度試験 法, http://www.jisc.go.jp, 2014 年 5 月 22 日アクセス.

\title{
ACTUAL SITUATION OF CONCENTRATION AND INVENTORY OF RADIOACTIVE CESIUM IN MATSUKAWAURA LAGOON SEDIMENT, FUKUSHIMA PREFECTURE
}

\author{
Koichi ARITA, Tohru YABE and Seiji HAYASHI
}

In order to qualitatively evaluate the current status of inventory of radioactive cesium in Matsukawaura Lagoon, profiles of radioactive cesium concentration in sediment cores and sediment characteristics were measured at 36 points. It was shown that sediment characteristics were different even at high concentration of radioactive cesium to the same extent. As a result, the inventory of radioactive cesium were also different. Even at high concentration of radioactive cesium, inventory in southwestern high mud content rate was less than the western. The total inventory of down to $20 \mathrm{~cm}$ of sediment throughout Matsukawaura Lagoon was estimated to be about $220 \mathrm{GBq}$, that more than $80 \%$ distributed to $15 \mathrm{~cm}$ shallower than has been revealed. 